\title{
Cardiomyocyte Regeneration from Circulating Bone Marrow Cells in Mice
}

\author{
YUKIO KURAMOCHI, RYUJI FUKAZAWA, MAKOTO MIGITA, JUN HAYAKAWA, \\ MARI HAYASHIDA, YOHKO UCHIKOBA, DAICHI FUKUMI, TAKASHI SHIMADA, AND \\ SHUNICHI OGAWA \\ Department of Pediatrics [Y.K., R.F., M.M., J.H., M.H., Y.U., D.F., S.O.], Department of Biochemistry \\ and Molecular Biology [M.M., T.S.], Nippon Medical School, Tokyo 113-8603, Japan
}

\begin{tabular}{|c|c|}
\hline \multicolumn{2}{|c|}{ ABSTRACT } \\
\hline $\begin{array}{l}\text { We investigated the role of circulating bone marrow cells } \\
\text { (BMC) in cardiomyocyte regeneration. BMC, isolated from } \\
\text { transgenic mice expressing enhanced green fluorescent protein } \\
\text { (GFP), were transplanted into lethally irradiated C57BL6 mice. } \\
\text { Five weeks after bone marrow transplantation (BMT), flow } \\
\text { cytometric analysis for GFP-positive cells confirmed reconstitu- } \\
\text { tion of transplanted bone marrow. Bone marrow transplant mice } \\
\text { subsequently underwent left coronary artery ligation (myocardial } \\
\text { infarction) or sham-operation, and were killed at } 1 \text { mo or } 3 \text { mo } \\
\text { after operation. Infarct size was similar in bone marrow trans- } \\
\text { plant mice at } 1 \text { mo ( } 47.1 \pm 5.9 \% \text { ) and at } 3 \text { mo ( } 45.3 \pm 7.8 \% \text { ), } \\
\text { and echocardiography at } 2 \text { and } 8 \text { wk revealed decreasing left } \\
\text { ventricular function. In infarcted heart, GFP-positive cells that } \\
\text { expressed desmin and troponin T-C were identified by confocal } \\
\text { microscopy. GFP and troponin T-C double-positive cells were } \\
\text { predominantly in the peri-infarcted region ( } 1 \text { mo, } 365 \pm 45 \\
\text { cells/50 sections; } 3 \text { mo: } 458 \pm 100 \text { cells/50 sections; } p<0.05 \\
\text { versus noninfarct, infarct, and sham-operated regions). Further- } \\
\text { more, BMC mobilization and differentiation into cardiomyocytes } \\
\text { was found to be complete within } 1 \text { mo after myocardial infarc- } \\
\text { tion. These results demonstrate that circulating BMC undergo } \\
\text { mobilization and differentiation in cardiac cells after myocardial } \\
\text { infarction. Future studies are required to determine the molecular }\end{array}$ & $\begin{array}{l}\text { signaling mechanisms responsible for this phenomenon. (Pediatr } \\
\text { Res 54: 319-325, 2003) } \\
\text { BM, bone marrow } \\
\text { BMC, bone marrow cells } \\
\text { BMT, bone marrow transplantation } \\
\text { BMT-MI mouse, bone marrow transplanted mouse with } \\
\text { myocardial infarction } \\
\text { E-GFP, enhanced green fluorescent protein } \\
\text { G-CSF, granulocyte-colony stimulating factor } \\
\text { GFP, green fluorescent protein } \\
\text { IH, immunohistological } \\
\text { Lo, lost myocardium } \\
\text { LV, left ventricular } \\
\text { LVIDd, left ventricular internal dimension at end-diastole } \\
\text { LVIDs, left ventricular internal dimension at end-systole } \\
\text { LVEF, left ventricular ejection fraction } \\
\text { MI, myocardial infarction } \\
\text { MT, Masson's trichrome } \\
\text { PE, phycoerythrin } \\
\text { Re, remaining viable myocardium } \\
\text { SCF, stem cell factor } \\
\text { TXRD, Texas red }\end{array}$ \\
\hline
\end{tabular}

Clinical therapies for treatment of MI have undergone recent progress; however, the efficacy of these therapies is limited by rapid necrosis of the myocardium and postinfarct ventricular remodeling (1-3). The replacement of lost tissue with skeletal or cardiac myocytes, termed cell therapy, has been investigated as a potential means to regenerate infarcted myocardium and improve post-MI survival (4-7). Moreover, endothelial cells, originating in host BM, have been shown to participate in vasculogenesis (8-9). This mechanism of neovascularization after myocardial ischemia

Received April 11, 2002; accepted December 23, 2002

Correspondence: Yukio Kuramochi, M.D., Department of Pediatrics, Nippon Medical School, 1-1-5 Sendagi, Bunkyo-ku, Tokyo 113-8603, Japan; e-mail: riosato@win.emial.ne.jp

DOI: 10.1203/01.PDR.0000078275.14079.77 or infarction has been extensively studied (10-13), and clinical trials are now ongoing to determine its efficacy in humans (14, 15). Recently, it has also been reported that BM contains pluripotent stem cells that are capable of differentiation into cardiomyocytes in vitro and in vivo (16-19). In our laboratory, we have established a murine whole BMT model in which murine marrow is reconstituted with $\mathrm{BMC}$ isolated from transgenic mice overexpressing E-GFP $(20,21)$. Using this model, we investigated the role of endogenous, circulating BMC in regeneration of cardiomyocytes after MI.

\section{MATERIALS AND METHODS}

All protocols conformed to the Guide for the Care and Use of Laboratory Animals published by the U.S. National Insti- 
tutes of Health, and were approved by the Animal Experimental Ethical Review Committee of Nippon Medical School (Approval number 13-4). E-GFP transgenic mice were kindly donated by Dr. Okabe (Osaka University, Osaka, Japan).

Bone marrow cells harvest and transplantation. Two days before BMT, 8-wk-old donor E-GFP transgenic mice were administered fluorouracil (5-FU; Kyowa, Tokyo, Japan) at a dose of $150 \mathrm{mg} / \mathrm{kg}$ i.v. to remove cycling cells (22). BMC were isolated from the femur and tibia and placed into $0.1 \mathrm{M}$ PBS. The cell suspension was passed through a $40-\mu \mathrm{m}$ filter (BD Biosciences, Franklin Lakes, NJ, U.S.A.), centrifuged, and resuspended in PBS at a concentration of $1 \times 10^{7}$ cells $/ \mathrm{mL}$.

Age-matched ( $8 \mathrm{wk}$ ) C57BL6 mice were irradiated with a lethal dose of $10 \mathrm{~Gy}$. Mice then received $5 \times 10^{6}$ donor BM mononuclear cells via tail vein injection.

Flow cytometric analysis. Five weeks after BMT, reconstituted $\mathrm{BM}$ and peripheral blood (PB) cell surface markers were analyzed by flow cytometry (BD Biosciences). Erythrocytes were removed with lysing solution (Nichirei, Tokyo, Japan), and BMC and PB cells were suspended in PBS and stained with PE-conjugated MAb. PE-conjugated MAb to Mac-1 (M1/ 70), Gr1 (RB6-8C5), CD45R/B220 (RA3-6B2), and Thy-1.2 (30-H12) were used to recognize macrophages, granulocytes, mature B lymphocytes, and T lymphocytes, respectively. Antibodies were purchased from BD PharMingen (San Diego, CA, U.S.A). BMC or PB cells were incubated with each of these antibodies for $30 \mathrm{~min}$ on ice, and washed with PBS. After preparation, the percentages of GFP-positive cells and cells positive for both GFP and PE were analyzed.

Left coronary artery ligation model. Left coronary artery ligation was performed on 12 BMT mice and six age-matched C57BL6 mice, whereas six BMT mice underwent a shamoperation. Each mouse was anesthetized with intraperitoneal pentobarbital $(50 \mathrm{mg} / \mathrm{kg})$, intubated, and mechanically ventilated with room air using a Harvard ventilator (model 683). After a left thoracotomy, the pericardium was opened. Left coronary artery ligation or sham-operation was then performed, as per the procedure reported in detail by Michael et al. (23).

Analysis of myocardial function. At 2 and 8 wk after operation, BMT-MI mice and sham-operated mice underwent transthoracic echocardiography under anesthesia with intraperitoneal pentobarbital $(50 \mathrm{mg} / \mathrm{kg})$ using an Acuson SEQUOIA 512 echocardiographic machine (Siemens Medical Solutions USA, Malvern, PA, U.S.A.). Two-dimensional short axis images were obtained at the level of mid-papillary muscle, and recorded. LVIDd and LVIDs were then measured, and LVEF was calculated as an index of contractile function.

Histologic examinations. One month after MI, at which time inflammatory cell infiltration into the site of MI and visceral pericardium disappears $(24,25)$, or 3 mo after MI, operated mice were killed with an overdose of intraperitoneal pentobarbital. Hearts were subsequently perfusion-fixed with $4 \%$ paraformaldehyde in $0.1 \mathrm{M}$ PBS to remove circulating blood cells and to allow for proper fixation of myocardium for histology studies. Frozen tissue sections $2-\mu \mathrm{m}$ thick were cut on a cryostat, air-dried, and histologically examined. IH stain,
MT stain, and hematoxylin-eosin stain were performed in a series of transverse sections. The transverse axis of the midregion was used to evaluate remaining viable (Re) and lost (Lo) myocardium in the left ventricular free wall (26-28), and the percentage infarct size was calculated as follows:

$\%$ infarct size $=100 \times \mathrm{Lo} /(\mathrm{Lo}+\mathrm{Re})$

Moreover, we divided the infarcted heart section into noninfarcted, infarcted, and peri-infarcted regions. Although the "at risk" area was uncertain, MT-stained slides allowed for clear recognition of the border between the infarct and noninfarcted area. The peri-infarcted region was defined as a scarred region within $100 \mu \mathrm{m}$ from the edge of the infarct border.

Immunohistological staining was also performed. A monoclonal desmin antibody (Novocastra, Newcastle, U.K.) (1:100 dilution), and a goat polyclonal troponin T-C antibody (Santa Cruz Biotechnology, Santa Cruz, CA, U.S.A.) (1:250 dilution) were used for cardiac-specific markers. A monoclonal CD45.2 antibody (BD PharMingen) (1:100 dilution) and a rat macrophages/monocyte antibody (Cosmobio, Tokyo, Japan) (1:30 dilution) were used for white blood cell-specific markers. Mouse MAb were detected with a VECTOR M.O.M. Immunodetection Kit (Vector Laboratories, Burlingame, CA, U.S.A.). TXRD-conjugated donkey anti-goat IgG (Cortex Biochem, San Leandro, CA, U.S.A.) (1:250 dilution) and TXRDconjugated goat anti-rat IgG (Molecular Probes, Eugune, OR, U.S.A.) (1:150 dilution) were used for secondary antibodies.

Fluorescent analysis was undertaken with a confocal, laser scanning microscope (Leica TCSSP, Heidelberg, Germany). Cells with GFP and troponin T-C double-positive staining were defined as regenerated cardiomyocytes, whereas GFP-negative and troponin T-C-positive cells were defined as endogenous cardiomyocytes. Random fields (at least 600 fields in each area) were examined by a blinded operator for appropriate assessment.

Statistical analysis. All data are reported as mean \pm SD. Results were analyzed by ANOVA (Scheffe's posthoc analysis). Differences were considered statistically significant at $p<$ 0.05 .

\section{RESULTS}

BM reconstitution. The percentage of GFP-positive cells in recipient $\mathrm{BM}$ was $96.7 \%$ at $1 \mathrm{mo}, 92.9 \%$ at $3 \mathrm{mo}$, and $90.8 \%$ at 6 mo after BMT, respectively. Moreover, GFP-positive cells within PB $(96.2 \%$ at 1 mo after BMT) had differentiated into Mac-1/Gr1 (23.4 \pm 0.9\%), CD45R/B220 (36.4 $\pm 1.2 \%)$, and Thy-1,2 $(53.6 \pm 2.1 \%)$ lineages. The proportion of each lineage in recipient PB was similar to pre-BMT.

Left coronary artery ligation. Two BMT-MI mice died within 2 wk after operation. Six BMT-MI mice, three C57BL6/J mice with MI, and three sham-operated BMT mice were killed at 1 mo after operation. Four BMT-MI mice, three C57BL6 mice with MI, and three sham-operated BMT mice were also killed at 3 mo after operation. The mortality rate of this ligation model was lower than in the previous reports (23), though a thinned and scarred left ventricular free wall was confirmed under microscopic observation. Furthermore, the peri-infarcted region was clearly distinguishable (Fig. 1A). 


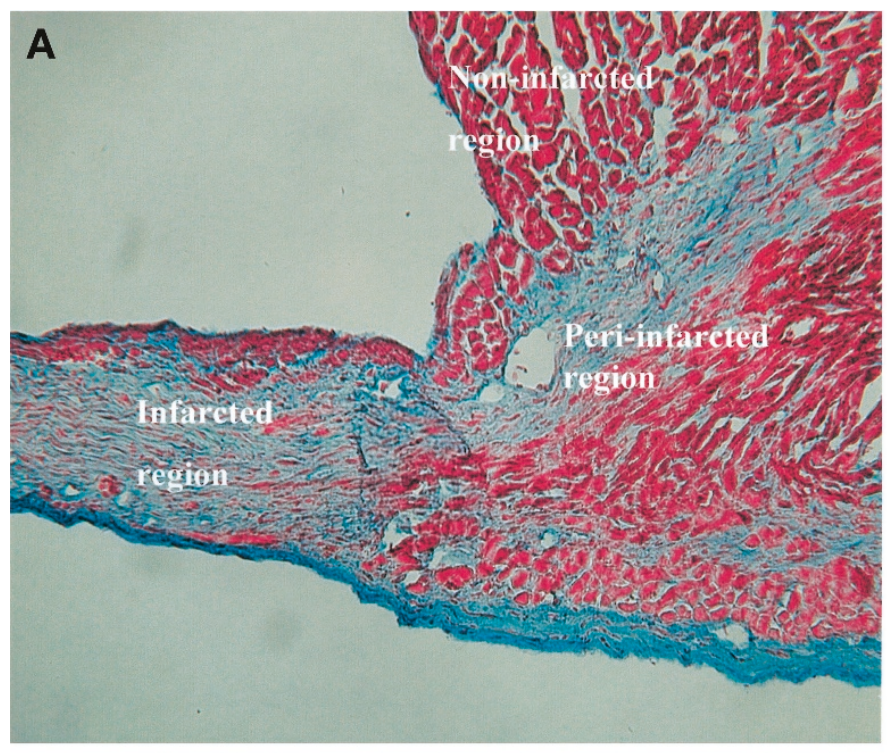

B
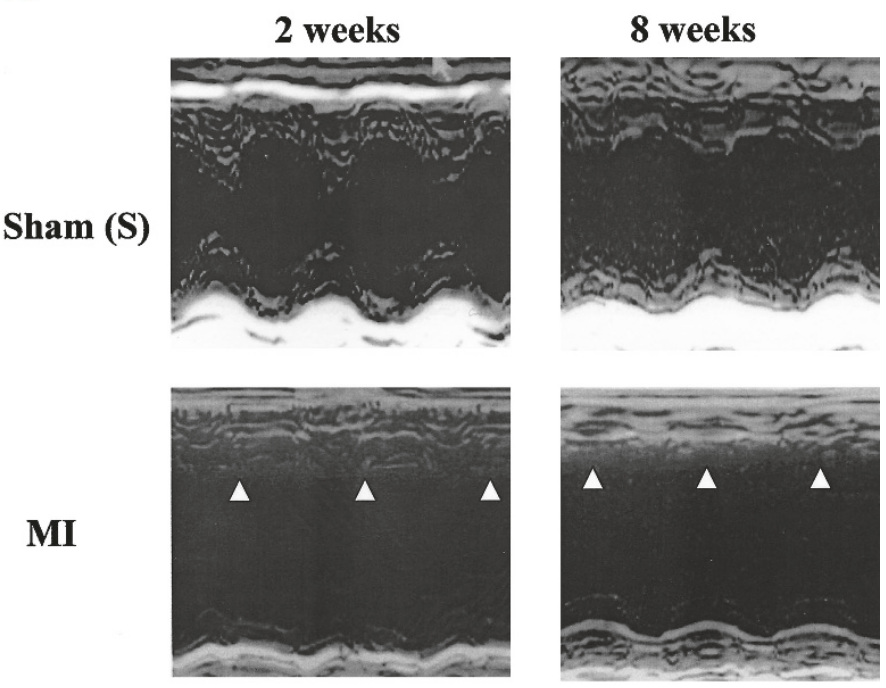

C

LVIDd (mm)

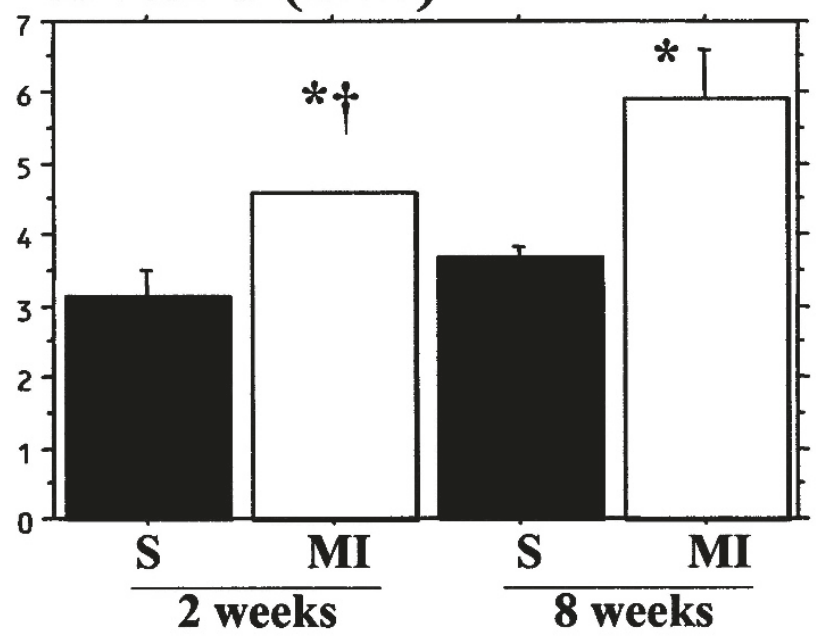

LVIDs (mm)

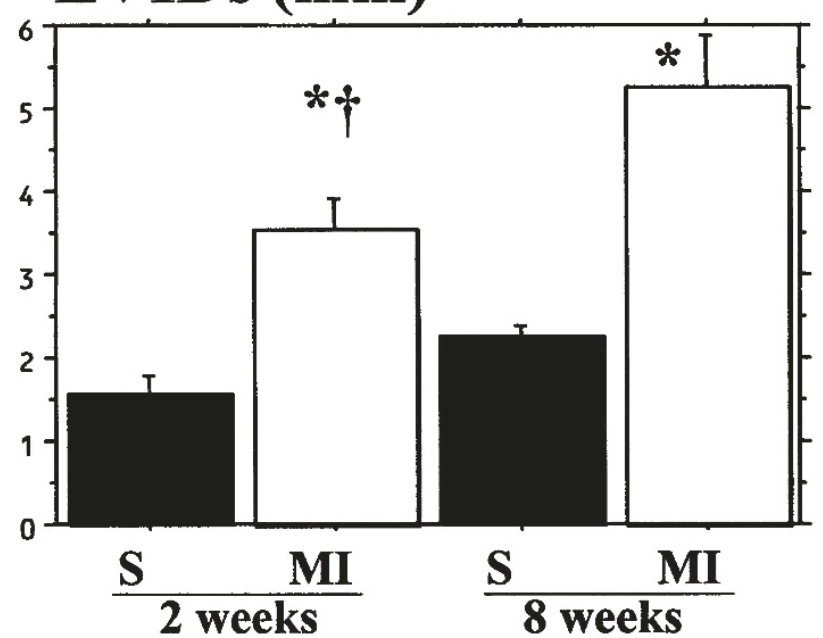

LVEF

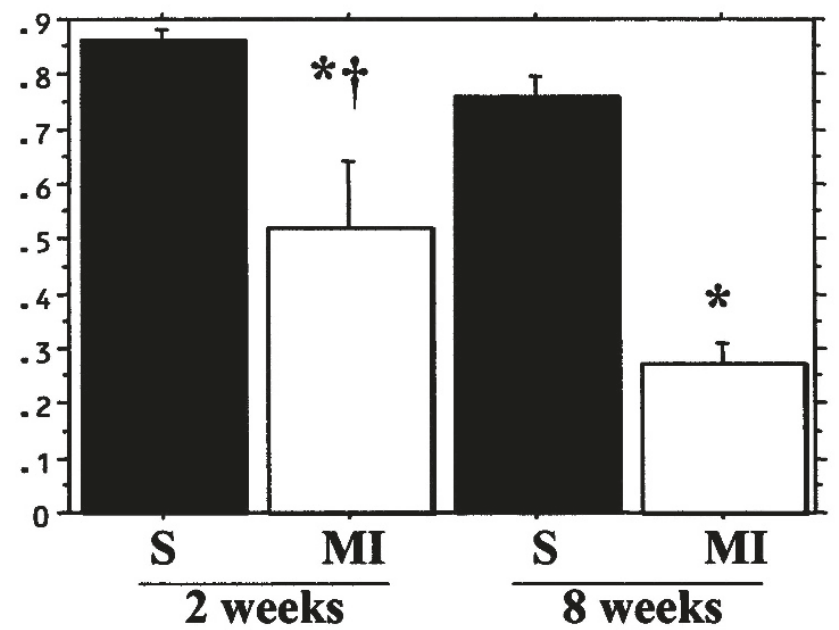

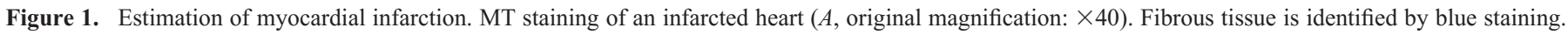

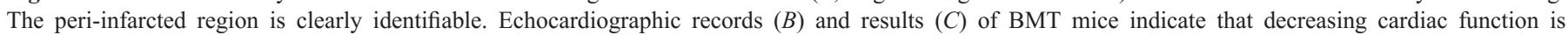

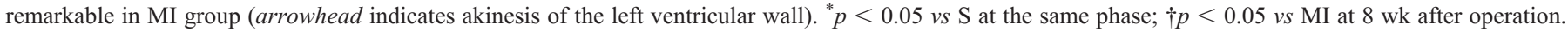
$S$, mice after sham-operation; $M I$, mice after myocardial infarction. 
Infarct size (as percentage LV) in BMT-MI mice was $47.1 \pm$ $5.9 \%$ at $1 \mathrm{mo}$, and $45.3 \pm 7.8 \%$ at $3 \mathrm{mo}$ ( $p$ value was not statistically significant).

Echocardiographic study. LVIDd, LVIDs, and LVEF were significantly different between BMT-MI mice and shamoperated mice. Furthermore, BMT-MI mice exhibited progressive impairments in echocardiographic parameters between at 2 and 8 wk after MI (Fig. 1, $B$ and $C$ ).
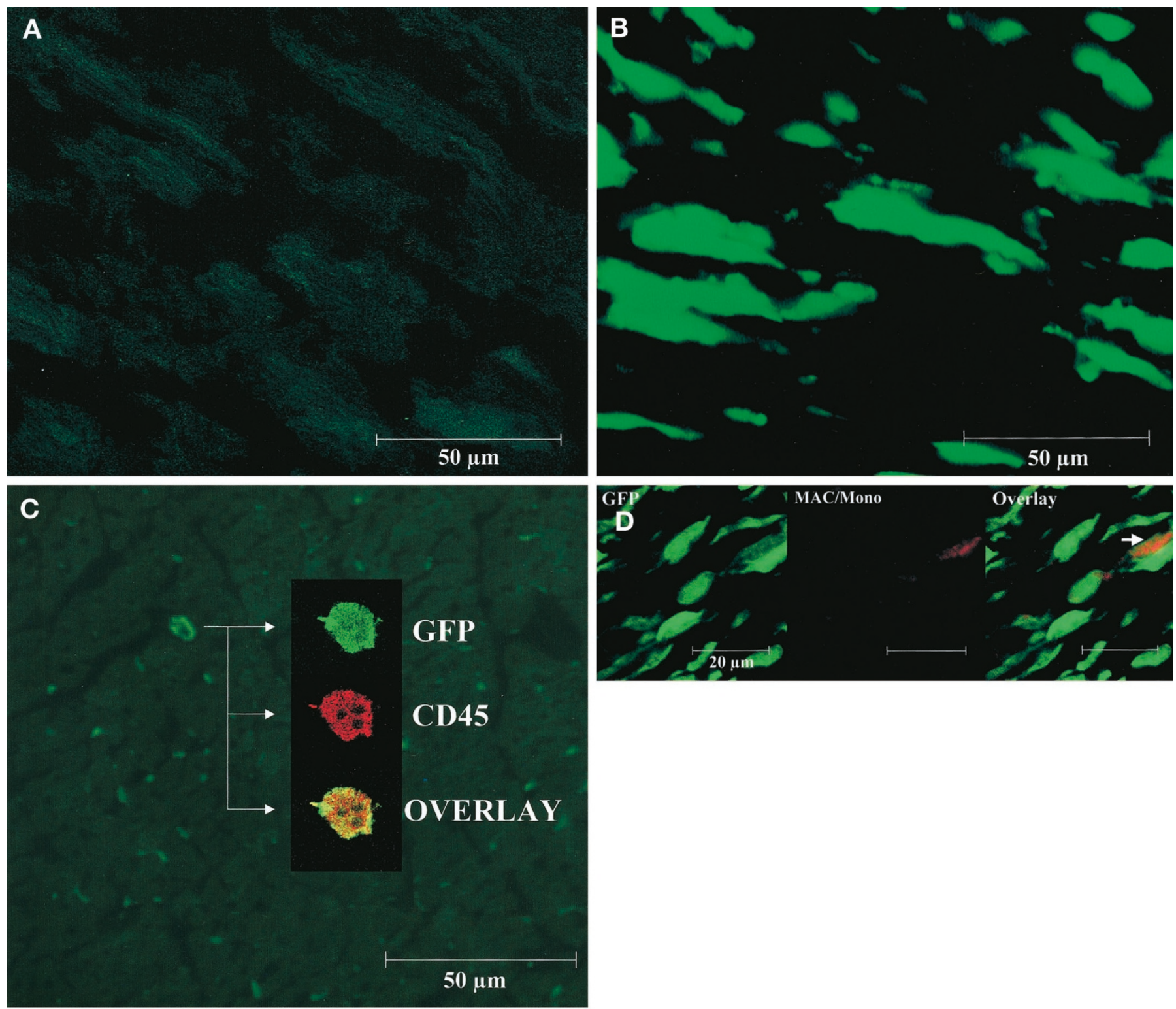
though cardiomyocytes exhibited a low, nonspecific autofluorescence under excitation light, E-GFP allowed unambiguous identification of the location of BM-derived cells. Mobilized BMCs were detected in greatest concentration in the periinfarcted region (Fig. 2, $A-C$ ) and within coronary vasculature (data not shown). GFP-positive cells, however, were rare in the other regions except as blood cells.

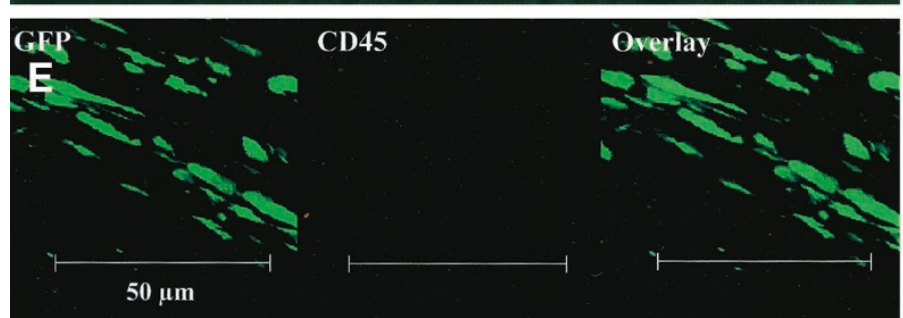

Figure 2. GFP-positive cells accumulate in peri-infarcted myocardium. Peri-infarcted region of C57BL6 mouse $(A)$, peri-infarcted region of BMT mouse $(B)$, and noninfarcted region of BMT mouse $(C)$ are shown under excitation light. In noninfarcted myocardium, a GFP-positive cell that expresses CD45 is seen (original magnification: $\times 400$; scale bar: $50 \mu \mathrm{m})$. However, GFP and macrophage/monocyte $(M A C / M O N O)$ antigen $(D)$ or CD45 $(E)$ positive cells are scarcely observed in the peri-infarcted region (arrow: macrophage). Original magnification: $\times 400$; scale bar: CD45 $50 \mu \mathrm{m}, \mathrm{MAC} / \mathrm{MONO} 20 \mu \mathrm{m}$. 


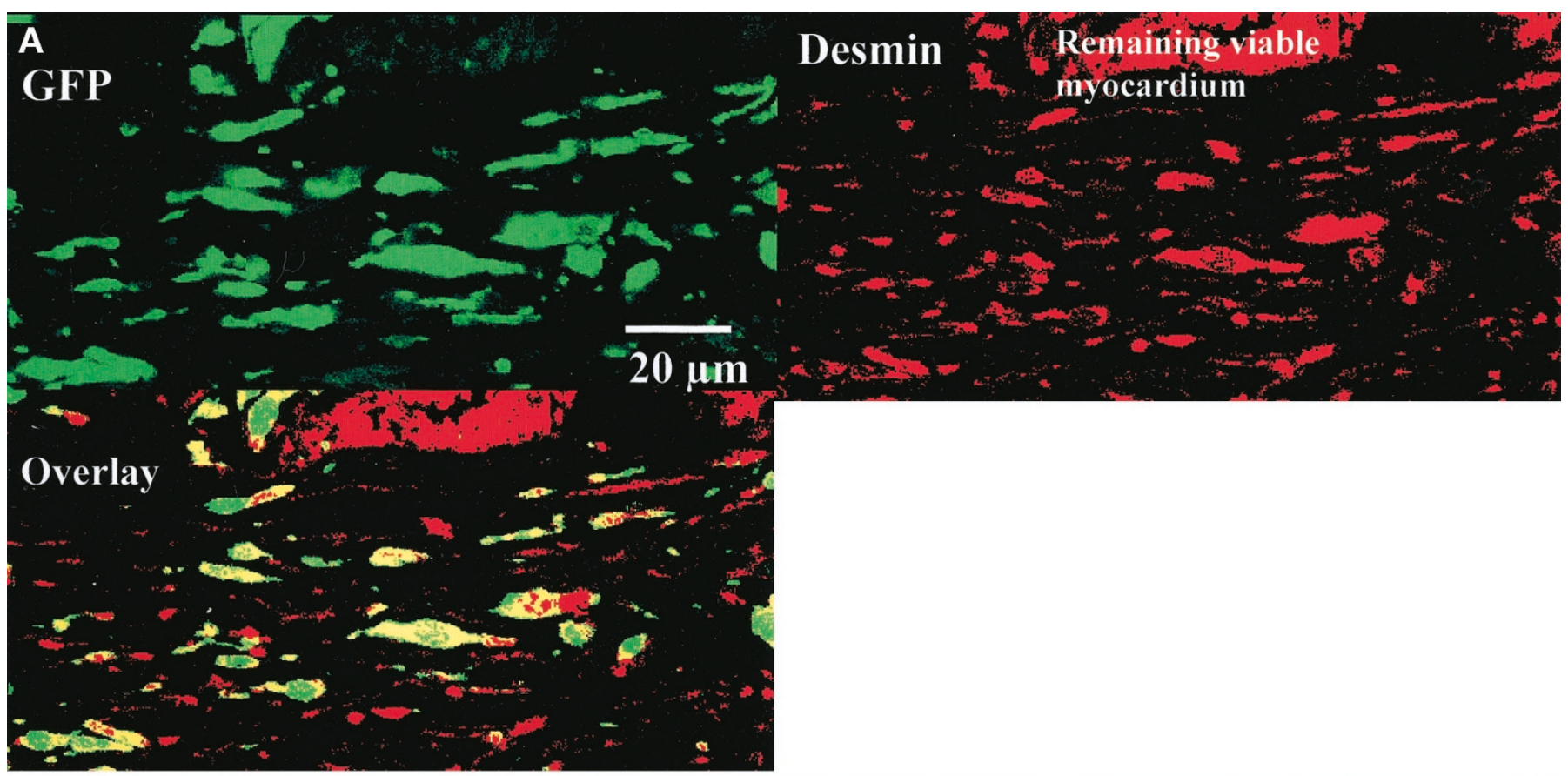

B

GFP

Troponin T-C

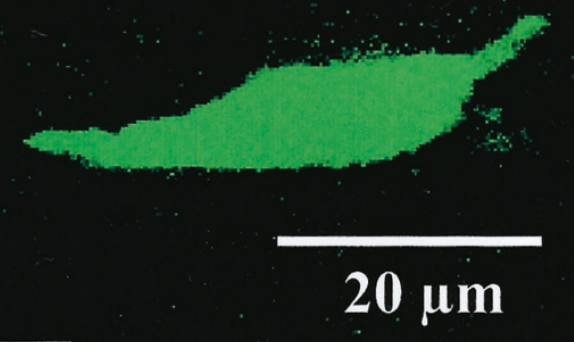

Overlay

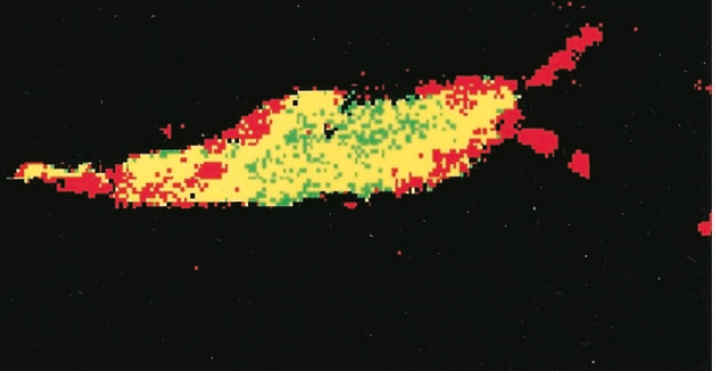

Figure 3. GFP-positive cells express desmin and troponin T-C. The peri-infarcted region at 1 mo is stained with desmin $(A)$ and troponin T-C $(B)$ antibodies (see "Materials and Methods"). In the overlay image, GFP-positive cells that express cardiac markers are yellow (original magnification: $\times 630$; scale bar: 20 $\mu \mathrm{m})$.

To ensure that GFP-labeled cells in the heart were not inflammatory cells, we performed immunohistological staining with CD45 and macrophage/monocyte specific antibodies. As shown in Figure 2, $D$ and $E$, inflammatory cells were scarce in number in the peri-infarcted region.

The mobilization and differentiation of BMC is completed within 1 mo after MI. Total cardiomyocyte number counted in each section was $12,393 \pm 2,600$ cells (noninfarct region, $10,637 \pm 1,861$ cells; peri-infarct region, $1,519 \pm 303$ cells; infarct region $395 \pm 245$ cells) at $1 \mathrm{mo}$, and 11,519 $\pm 1,735$ cells (noninfarct region, 9,084 $\pm 1,556$ cells; peri-infarct region, 2,225 \pm 228 cells; infarct region, $210 \pm 44$ cells) at $3 \mathrm{mo}$ after MI. GFP-positive cells in the infarcted heart also coexpressed desmin and troponin T-C (Fig. 3). These cells were 

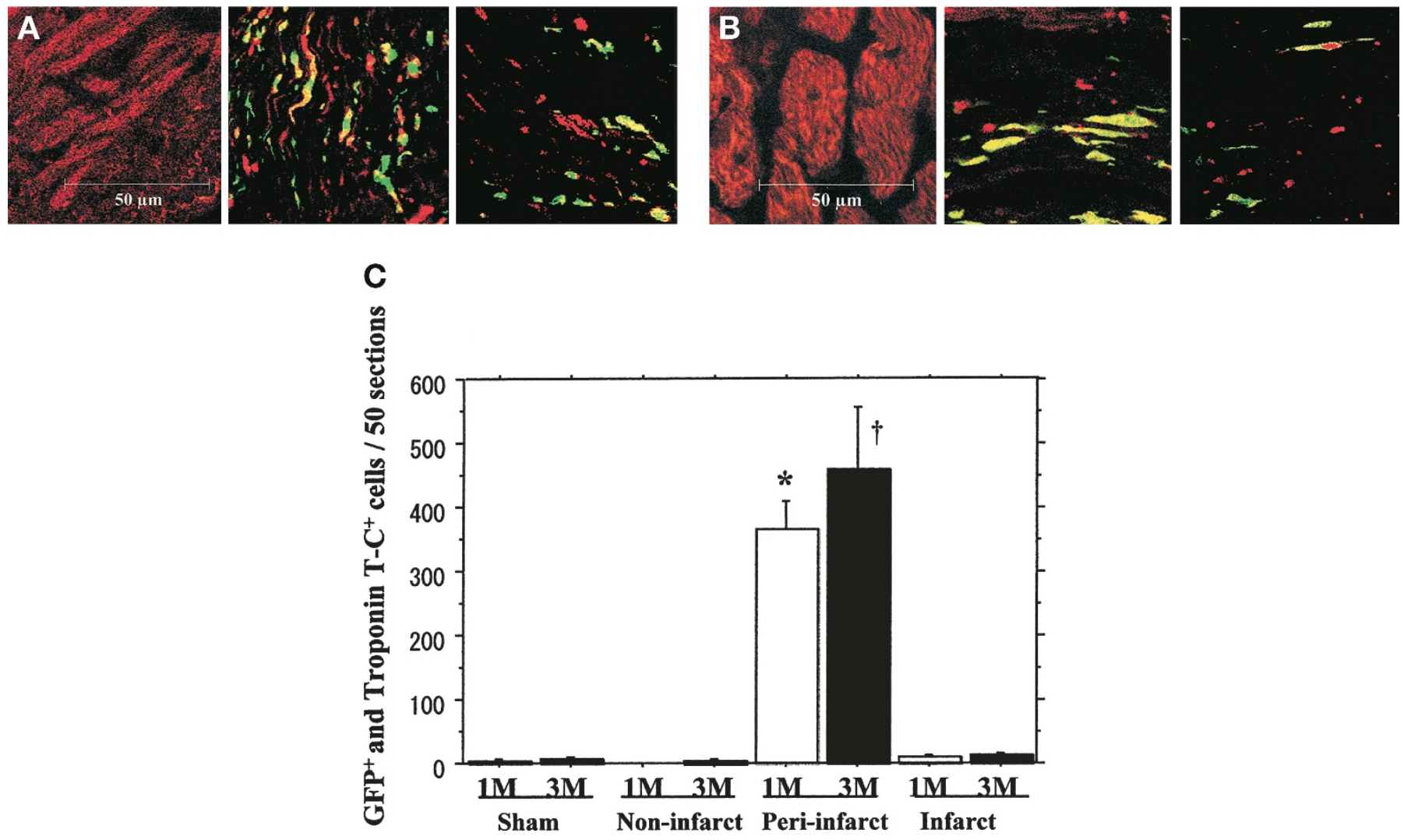

Figure 4. Cardiomyocyte regeneration at $1 \mathrm{mo}$ and at 3 mo after MI. Overlay views of noninfarct (left), peri-infarct (mid), and infarct (right) regions at 1 mo $(A)$ and at 3 mo $(B)$ are shown (GFP: green; troponin T-C: red; GFP and troponin T-C: yellow). (C) The number of regenerated cardiomyocytes in 50 sections is indicated. BMC mobilization and differentiation into cardiomyocytes are observed predominantly in the peri-infarcted region, and are almost completed within 1 mo after MI. *, $\uparrow p<0.05$ vs Sham, Noninfarct, and Infarct at the same phase. Noninfarct, noninfarcted region; Peri-infarct, peri-infarcted region; Infarct, infarcted region; Sham, sham-operated region.

$20-50 \mu \mathrm{m}$ in length. The number of GFP and troponin T-C double-positive cells was highest in the peri-infarcted region (1 mo: $365 \pm 45$ cells $/ 50$ sections; 3 mo: $458 \pm 100$ cells $/ 50$ sections; $p<0.05$ versus sham, noninfarct, infarct regions). However, the difference between the values in each region at 1 and 3 mo after MI was not statistically significant (Fig. 4). The percentage of newly formed cardiomyocytes for the entire LV was $0.04 \pm 0.02 \%$ at $1 \mathrm{mo}$ and $0.04 \pm 0.03 \%$ at $3 \mathrm{mo}$ after MI.

\section{DISCUSSION}

Recently, Jackson et al. (13) documented the regeneration of cardiac muscle from BM stem cells using a LacZ transgenic murine BMT model. However, animals were followed for only $1 \mathrm{mo}$, and quantitative data in each region was not shown. To our knowledge, this is the first study to document cardiomyocyte regeneration from endogenous BMC for more than 1 mo.

In our results, GFP and troponin T-C double-positive cells accumulated predominantly in the peri-infarcted region. Beltrami et al. (29) have reported that human cardiac myocytes also divide most in the region adjacent to the infarct after MI. These results suggest that repopulation of cardiomyocytes is targeted to repair the injured myocardium and its surroundings. Although some cytokines and/or growth factors, such as GCSF and SCF, may be involved $(26,30)$, the mechanism by which communication occurs between BMC and cardiomyocytes has not yet been fully elucidated.
Cardiomyocyte regeneration from endogenous BMC is small in number $(0.04 \pm 0.02 \%$ at $1 \mathrm{mo}$ and $0.04 \pm 0.03 \%$ at $3 \mathrm{mo}$ ), and is essentially complete within 1 mo after MI. Echocardiography revealed that newly replaced cardiomyocytes were not sufficient to improve cardiac function. Although this result can be expected, we believe that site-specific accumulation of circulating BMC and differentiation into cardiomyocytes are important events for certain clinical situations. Evidence that patients suffering angina before MI have better in-hospital prognosis and smaller infarcts has been previously reported (31-36). Orlic et al. (26) reported that G-CSF and SCF mediated mobilization of BM cells into infarcted hearts increased newly formed cardiomyocytes, and decreased mortality and infarct size. Although ischemic preconditioning and neovascularization likely play main roles in these clinical contexts, BMC-derived cardiomyocytes may also be important in the temporal repair of damaged cardiac tissues. Furthermore, it may be worth investigating whether there is an ageassociated difference in cardiomyocyte regeneration.

Regarding potential problems and limitations of this experimental design, it is considerable that irradiation affected the recipient heart and/or other organs. Moreover, Lin et al. (37) have reported that circulating endothelial cells produced from transplanted marrow-derived cells display a greater proliferation rate than native cells. It is therefore possible that some differences exist between endogenous BMC and transplanted 
BMC. These factors must be taken into consideration to accurately assess the results of this study.

\section{CONCLUSION}

In conclusion, cardiomyocyte regeneration by circulating BMC was observed largely in the peri-infarcted region, and was essentially complete by 1 mo post-MI. However, regenerated cardiomyocytes from BMC were small in number, and not sufficient to improve cardiac function. Further investigation is required to determine the molecular signals responsible for mobilization and differentiation of BMC after MI.

\section{REFERENCES}

1. Reimer KA, Jennings RB 1979 The wavefront phenomenon of myocardial ischemic cell death. II. Transmural progression of necrosis within the framework of ischemic bed size (myocardium at risk) and collateral blood flow. Lab Invest 40:633-644

2. Anversa P, Li P, Zhang X, Olivetti G, Capasso JM 1993 Ischemic myocardial injury and ventricular remodeling. Cardiovasc Res 27:145-157

3. Pfeffer MA, Braunward E 1990 Ventricular remodeling after myocardial infarction: experimental observation and clinical implications. Circulation 81:1161-1172

4. Jain M, DerSimonian H, Brenner DA, Ngoy S, Teller P, Edge ASB, Zawadzka A, Watzel K, Sawyer DB, Colucci WS, Apstein CS, Liao R 2001 Cell therapy attenuates deleterious ventricular remodeling and improves cardiac performance after myocardial infarction. Circulation 103:1920-1927

5. Murry CE, Wiseman RW, Schwartz SM, Hauschka SD 1996 Skeletal myoblast transplantation for repair of myocardial necrosis. J Clin Invest 98:2512-2523

6. Reinlib L, Field L 2000 Cell transplantation as future therapy for cardiovascular disease? A workshop of the National Heart, Lung, and Blood Institute. Circulation 101:e182-e187

7. Reinecke H, Zhang M, Bartosek T, Murry CE 1999 Survival, integration, and differentiation of cardiomyocyte graft. A study in normal and injured rat hearts. Circulation 100:193-202

8. Takahashi T, Kalka C, Masuda H, Chen D, Silver M, Kearney M, Magner M, Isner JM, Asahara T 1999 Ischemia- and cytokine-induced mobilization of bone marrowderived endothelial progenitor cells for neovascularization. Nat Med 5:434-438

9. Asahara T, Masuda H, Takahashi T, Kalka C, Pastore C, Silver M, Kearne M, Magner M, Isner JM 1999 Bone marrow origin of endothelial progenitor cells responsible for postnatal vasculogenesis in physiological and pathological neovascularization. Circ Res 85:221-228

10. Asahara T, Takahashi T, Masuda H, Kalka C, Chen D, Iwaguro H, Inai Y, Silver M, Isner JM 1999 VEGF contributes to postnatal neovascularization by mobilizing bone marrow-derived endothelial progenitor cells. EMBO J 18:3964-3972

11. Kamihata H, Matsubara H, Nishiue T, Fujiyama S, Tsutsumi Y, Ozono R, Masaki H, Mori Y, Iba O, Tateishi E, Kosaki A, Shintani S, Murohara T, Imaizumi T, Iwasaka $\mathrm{T} 2001$ Implantation of bone marrow mononuclear cells into ischemic myocardium enhances collateral perfusion and regional function via side supply of angioblasts, angiogenic ligands, and cytokines. Circulation 104:1046-1052

12. Fuchs S, Baffour R, Zhou YF, Shou M, Pierre A, Tio FO, Weissman NJ, Leon MB Epstein SE, Kornowski R 2001 Transendocardial delivery of autologous bone marrow enhances collateral perfusion and regional function in pigs with chronic experimental myocardial ischemia. J Am Coll Cardiol 37:1726-1732

13. Jackson KA, Majka SM, Wang H, Pocius J, Hartley CJ, Majesky MW, Entman ML, Michael LH, Hirschi KK, Goodell MA 2001 Regeneration of ischemic cardiac muscle and vascular endothelium by adult stem cells. J Clin Invest 107:1395-1402

14. Losordo DW, Vale PR, Symes JF, Dunnington CH, Esakof DD, Maysky M, Ashare $\mathrm{AB}$, Lathi K, Isner JM 1998 Gene therapy for myocardial angiogenesis: initial clinical results with direct myocardial injection of phVEGF165 as sole therapy for myocardial ischemia. Circulation 98:2800-2804
15. Seiler C, Pohl T, Wustmann K, Hutter D, Nicolet PA, Windecker S, Eberli FR, Meier B 2001 Promotion of collateral growth by granulocyte-macrophage colonystimulating factor in patients with coronary artery disease. A randomized, doubleblind, placebo-controlled study. Circulation 104:2012-2017

16. Makino S, Fukuda K, Miyoshi S, Konishi F, Kodama H, Pan J, Sano M, Takahashi T, Hori S, Abe H, Hata J, Umezawa A, Ogawa S 1999 Cardiomyocytes can be generated from marrow stromal cells in vitro. J Clin Invest 103:697-705

17. Tomita S, Li RK, Weisel RD, Mickle DAG, Kim EJ, Sakai T, Jia ZQ 1999 Autologous transplantation of bone marrow cells improves damaged heart function. Circulation 100(suppl II):II-247-II-256

18. Orlic D, Kajstura J, Chimenti S, Jakoniuk I, Anderson SM, Li B, Pickel J, McKay R, Nadal-Ginard B, Bodine DM, Leri A, Anversa P 2001 Bone marrow cells regenerate infarcted myocardium. Nature 410:701-705

19. Toma C, Pittenger MF, Cahill KS, Byrne BJ, Kessler PD 2002 Human mesenchymal stem cells differentiate to a cardiomyocyte phenotype in the adult murine heart. Circulation 105:93-98

20. Cody CW, Prasher DC, Westler WM, Prendergast FG, Ward WW 1993 Chemical structure of the hexapeptide chromophore of the Aequorea green-fluorescent protein. Biochemistry 32:1212-1218

21. Okabe M, Ikawa M, Kominami K, Nakanishi T, Nishimune Y 1997 'Green mice' as a source of ubiquitous green cells. FEBS Lett 407:313-319

22. Ono K, Takii T, Onozaki K, Ikawa M, Okabe M, Sawada M 1999 Migration of exogenous immature hematopoietic cells into adult mouse brain parenchyma under GFP-expressing bone marrow chimera. Biochem Biophys Res Commun 262:610 614

23. Michael LH, Entman ML, Hartley CJ, Youker KA, Zhu J, Hall SR, Hawkins HK, Berens K, Ballantyne CM 1995 Myocardial ischemia and reperfusion: a murine model. Am J Physiol 269:H2147-H2154

24. Sun Y, Weber KT 2000 Infarct scar: a dynamic tissue. Cardiovasc Res 46:250-256

25. Sun Y, Zhang JQ, Zhang J, Lamparter S 2000 Cardiac remodeling by fibrous tissue after infarction in rats. J Lab Clin Med 135:316-323

26. Orlic D, Kajstura J, Chimenti S, Limana F, Jakoniuk I, Quaini F, Nadal-Ginard B, Bodine DM, Leri A, Anversa P 2001 Mobilized bone marrow cells repair the infarcted heart, improving function and survival. Proc Natl Acad Sci U S A 98:10344-10349

27. Olivetti G, Capasso JM, Meggs LG, Sonnenblick EH, Anversa P 1991 Cellular basis of chronic ventricular remodeling after myocardial infarction in rats. Circ Res 68:856-869

28. Beltrami CA, Finato N, Rocco M, Feruglio GA, Puricelli C, Cigola E, Quaini F, Sonnenblick EH, Olivetti G, Anversa P 1994 Structural basis of end-stage failure in ischemic cardiomyopathy in humans. Circulation 89:151-163

29. Beltrami AP, Urbanek K, Kajstura J, Yan SM, Finato N, Bussani R, Nadal-Ginard B, Silvestri F, Leri A, Beltrami CA, Anversa P 2001 Evidence that human cardiac myocytes divide after myocardial infarction. N Engl J Med 344:1750-1757

30. Matsui Y, Zsebo KM, Hogan B 1990 Embryonic expression of a haematopoietic growth factor encoded by the S1 locus and the ligand for c-kit. Nature 347:667-669

31. Kloner RA, Shook T, Przyklenk K, Davis VG, Junio L, Matthews RV, Burstein S, Gibson M, Poole WK, Cannon CP, McCabe CH, Braunwald E 1995 Previous angina alters in-hospital outcome in TIMI 4: a clinical correlate to preconditioning? Circulation 91:37-45

32. Ottani F, Galvani M, Ferrini D, Sorbello F, Limonetti P, Pantoli D, Rusticali F 1995 Prodromal angina limits infarct size: a role for ischemic preconditioning. Circulation 91:291-297

33. Ishihara M, Sato H, Tateishi H, Kawagoe T, Shimatani Y, Kurisu S, Sakai K, Ueda K 1997 Implications of prodromal angina pectoris in anterior wall acute myocardial infarction: acute angiographic findings and long-term prognosis. J Am Coll Cardiol 30:970-975

34. Kloner RA, Shook T, Antman EM, Cannon CP, Przyklenk K, Yoo K, McCabe CH, Braunwald E 1998 Prospective temporal analysis of the onset of preinfarction angina versus outcome: an ancillary study in TIMI-9B. Circulation 97:1042-1045

35. Dana A, Yellon DM 1998 Cardioprotection by pre-infarct angina: is it ischaemic preconditioning? Eur Heart J 19:367-369

36. Andreotti F, Pasceri V, Hackett DR, Davies GJ, Haider AW, Maseri A 1996 Preinfarction angina as a predictor of more rapid coronary thrombolysis in patients with acute myocardial infarction. N Engl J Med 334:7-12

37. Lin Y, Weisdorf DJ, Solovey A, Hebbel RP 2000 Origins of circulating endothelial cells and endothelial outgrowth from blood. J Clin Invest 105:71-77 